\title{
THE LEGAL NATURE AND THE FRAMEWORK FOR COOPERATIVE ACTIVITIES
}

\author{
Miodrag Mićović ${ }^{1}$
}

\begin{abstract}
Summary
The subject of the paper are issues related to the legal nature of cooperatives and legal framework for the cooperative activities. When it comes to the legal nature of the cooperatives, newly enacted rules have not made substantial changes with regard to the previously applicable classical concept of cooperatives. Along with that, legal framework for cooperatives is consisted of certain special rules, which differ from the rules that apply for companies, such as: number of founders of the cooperative; persons who may be members of the cooperative; activity; basic capital; the right to vote, quorum and decision-making; profit distribution.

The aim of this paper is to highlight the role of cooperatives in the stabilization of the economy, as well as to point out the need to amend the rules contained in the Law on Cooperatives in accordance with the latest developments of the cooperative organization. The legal analysis has shown that it is necessary to: alter the attitude of the cooperative as a form of organization of natural persons; relativize the effect of the principle of one cooperative member - one vote, self-help and identity in order to strengthen the market functions of the cooperatives. The analysis of the co-operative rules and conclusions are drawn out using the comparative legal method.
\end{abstract}

Key words: cooperative, cooperative member, voting right, principles, investor members JEL: $Q 19$.

1 Miodrag Mićović Ph.D., Full Professor, University of Kragujevac, Faculty of Law, Jovana Cvijića Street no. 1, 34000 Kragujevac, Serbia, Phone: +381 34306 530, E-mail: mmicovic@jura.kg.ac.rs. 


\section{Introduction}

The cooperatives exist approximately for two hundred years. ${ }^{2}$ They operate in different social (economical) fields and have a longer life expectancy than profit (business) societies. Almost half of the world population provides the funds thanks to the cooperatives. $^{3}$ In the world, there are three times more members of the cooperatives than the shareholders, while in the fast growing states of the BRIC group, there are four times more members of the cooperatives than the shareholders. ${ }^{4}$

2 The first cooperative in Serbia was founded in 1846 in Backi Petrovac. In 1895 the Association of Serbian agricultural cooperatives was established, that participated in the founding of the International Cooperative Alliance, London, 1895. Railway savings-loan cooperative was established in 1891 (seven years after putting into traffic the first railway; it had over 100,000 cooperative members, and employed around 100 workers), in order to help railway workers overcoming material difficulties, and the first agricultural-loan cooperative was founded 1894 in the village Vranovo, near Smederevo, in order to protect poor farmers from usurers and commercial speculators (Popović, V., 2012; Predlog Zakona o zadrugama; Izveštaj o zadrugama i zadrugarstvu).

3 In the European Union, 246,000 registered cooperatives employ 4.8 million people and have 144 million members of cooperatives, which means that every third citizen of the EU is a member of some cooperative. In the US, every fourth citizen is a member of some cooperative, the largest energy companies are cooperatives (Izveštaj o zadrugama i zadrugarstvu).

4 Cooperatives are particularly prominent in several sectors. Agricultural cooperatives in Europe have a total of $60 \%$ of market share in the area of processing and marketing of agricultural products and around $50 \%$ shares in the procurement of raw materials. In the US, cooperatives have a $28 \%$ of the market share in the processing and marketing of agricultural products and $26 \%$ in the procurement of raw materials. Worldwide there are about 53000 credit cooperatives and credit unions. In Europe there are about 4,200 credit cooperative banks with 63,000 branches. These cooperative banks have 50 million members (about 10\% of the European population), 181 million clients, 780000 employees, 5.65 billion Euros assets and average market share of about $20 \%$. In the European retail sector 3200 consumer cooperatives employ 400000 people, have 29 million members, 36,000 sales outlets and 73 billion Euros turnover. When we talk about the service sector, the presence of cooperatives is particularly significant in the US, where nearly 1,000 cooperatives control $40 \%$ of the national electricity distribution system, covering $75 \%$ of the territory of the United States and providing services to 37 million members and their households. Cooperatives play a leading role in supplying drinking water in Argentina and Bolivia, where a large urban cooperative supplies water to some 700000 beneficiaries. Workers are organized into cooperatives in various industrial branches. In Italy there are over 25000 workers' cooperatives. In Spain, between 1998 and 2008 was established about 14000 new cooperatives, of which $75 \%$ are the working cooperatives. The sectoral distribution of workers' cooperatives varies from country to country. In France, there are many workers' cooperatives in production and construction, and only a small number in the service sector. In Uruguay, on the other hand a small number of cooperatives is present in the area of production, while a large number of cooperatives is present in the field of transport and services. According to the International Federation of cooperative mutual insurance, cooperatives, in 2008, in the global insurance market had a share of 25\%, of which $44 \%$ in Germany, 39\% in France, 38\% in Japan, 30\% in the US and Canada (Borzaga, Galera, 2012). 
The cooperatives play a key role in the stabilization of the economy, particularly in the sectors marked with a high degree of insecurity and price instability, such as the sector of agriculture and finances. Cooperative banks in Europe, as well as the credit unions in the US, represent a factor of the stabilization of the banking system. ${ }^{5}$ Since the establishment, the cooperatives constantly adapt to circumstances ${ }^{6}$ (new cooperative forms emerge), appearing as a significant factor in solving problems of local community or different user groups (Borzaga, Galera, 2012). In times of crisis, cooperatives solve the employment and business issues ${ }^{7}$ in a more efficient way than commercial companies (Borzaga, Galera, 2012; Izveštaj o zadrugama i zadrugarstvu).

Cooperatives have certain drawbacks reflected in limited access to sources of capital in the capital market, due to which the cooperatives are oriented on their own resources or on loans (Jurić, 2006). Therefore in the last two decades, a cooperative law undergone reforms,${ }^{8}$ in order to, in accordance with the principle of freedom of entrepreneurship, ensure that cooperatives have the equal position in relation to the other economic entities (Izveštaj o zadrugama i zadrugarstvu) as well as to provide additional options for the collection of their own capital (Avsec, 2009). The reforms are characterized by a tendency of diminishing differences between the cooperatives and the companies, in

5 In Serbia since 2005, the establishment of savings and loan cooperatives is prohibited, but at the same time the largest cooperative banks in the world (Credit Agricole Bank, as the largest global cooperative system, and Raiffeisen Bank, the oldest cooperative bank in Europe and the world) have permission to operate (Izveštaj o zadrugama i zadrugarstvu).

6 In theory of the cooperative movement, more than one model of cooperative organization stands out, among which three particularly influenced the cooperative movement in our region, namely: Rochdale model (developed in England after the strike of weavers in 1843 , which enabled free entry and exit from the cooperative, equality of cooperative members, regardless of the amount of registered shares), Raiffeisen model (developed in Germany in 1848 , at the time of the great famine, in order to provide opportunities to poor class society to be supplied with basic groceries; in 1854 the first credit union was founded, where cooperative members had joint and unlimited liability, while a surplus of income were entered into a cooperative reserve fund), Schulze-Delic model (developed in Germany in 1849, excludes state aid, allowing the division's reserve fund, attracting capital through the remuneration, limited liability of cooperative members) (Izveštaj o zadrugama i zadrugarstvu).

7 According to the opinion of the certain authors, cooperatives were created as a response of workers to poor working conditions, increased unemployment and poverty, as an alternative to the capitalist economic system (Morel, 2014).

8 UN Resolution 64/136 on cooperatives encourages the governments to consider the legal aspects of regulating the activities of cooperatives in order to increase the growth and sustainability of cooperatives (in the socio-economic environment that is rapidly changing), through the provision of equal opportunities for cooperatives relative to other business and social enterprises, including tax reliefs and access to financial services and markets (Izveštaj o zadrugama i zadrugarstvu).

EP 2017 (64) 3 (1205-1218) 
favor of the latter model. ${ }^{9}$

In a comparative law, there has been visible a different approach to the issues related to cooperatives and the system of cooperative societies, in one group of countries these issues are regulated under the Code (trade - Czech Republic, Slovakia or civil - Italy); in the second group of countries the cooperative issues are regulated under the Law on Cooperatives of general character (Greece, Portugal, Bulgaria, Croatia, Slovenia, Bosnia and Herzegovina); in the third group more specific cooperative laws are adopted (Austria, Germany, France, Spain). ${ }^{10}$ In Republic of Serbia, this matter is regulated by a single law, the Law on Cooperatives (LOC), in accordance with the recommendations of the International Cooperative Alliance.

For the reformed cooperative law, the rules contained in Regulation EU 1435/03 of July 22, 2003 on the Statute of the European Cooperative Society have a special significance, as well as the American Uniform Limited Cooperative Association Act (ULCAA), which was passed in 2007. The legal analysis of the abovementioned rules as well as the rules contained in LOC will be conducted using the comparative legal method in combination with inductive and deductive research method. Special focus in this paper will be placed to issues related to the legal status and legal nature of the cooperatives, as well as those which define the legal framework, set limits in terms of organization, investment, management, business object. ${ }^{11}$ The legal analysis of these issues is aiming to determine which national rules governing cooperatives should be amended or defined de lege ferenda, in order to bring Serbian regulations on cooperatives into line with the latest cooperative developments worldwide.

\section{The legal nature of cooperatives}

The question of the legal nature of cooperatives is one of the fundamental questions that legal theory tried to give an answer to. Cooperatives are determined as a form of a company or as a sui generis association (Vitez, 1998). Due to the reform of the cooperative sector, this issue becomes current again.

In order to be able to give an answer to this question, one needs to take into consideration the rules governing cooperative values and principles. These rules are defined by the International Cooperative Alliance in 1995 and implemented in

9 There is an attitude that tendencies of 'compensation' of all forms of business organizations should be stopped, that they are contrary to the aims of the cooperative organization, which is why in some countries (Sweden) it is not accepted that its members acquire the status of persons who do not use the services of the cooperative (Hagen, 2002; Avsec, 2009).

10 There are 14 different laws governing coopertatives in Spain (Ibáñez, 2011).

11 Statistically observed, the system of cooperative societies in Serbia is in a difficult position. The number of active cooperatives is stagnant (there are about 2200), with the largest number of agricultural cooperatives (65\%), which absorb the largest number of employees (of 4707 employees, $80.6 \%$ is employed in these cooperatives), and approximately 120,000 citizens of Serbia are members of some of the cooperatives (Predlog Zakona o zadrugama). 
our and some international legal acts. ${ }^{12}$ According to the LOC, the cooperatives are based on the values of self-help (characterized by the congruence of the cooperative members and service beneficiaries, members of the cooperative are not only investors of capital and administrators, but also the beneficiaries of cooperative services in the broadest sense of the word: as suppliers, customers, employees, etc) (Avsec, 2009), self-responsibility, democracy, equality, fairness and solidarity (Art. 4, par. 2). For the realization of cooperative values, establishment and operation of cooperatives are important principles that include: voluntary and open membership (cooperatives are open to all persons who can use its services); democratic member management and control (every member of the cooperative shall have equal right in the management and control of the business, according to the principle of one member - one vote); economic cooperation of members (cooperative members contribute to the capital and therefore have the right to surplus distribution); autonomy and independence (in relations with the state and other organizations); education, training and information; collaboration with other cooperatives; care of the community (cooperatives are committed to sustainable development in accordance with policies approved by the members) (Art. 4, par. 3). If aforementioned principles are taken into account (primarily the principle of identity, coincidence of service beneficiaries and members of the cooperative, the principle of cooperation openness, the principle of democratic control of cooperative operations by its members), ${ }^{13}$ together with the main objective of the cooperative organization (meeting the needs of its members and not profit-making) (Timčić, 2016), it could be said that cooperatives, by their nature, are sui generis associations. They can not be organized as a company, nor can they join or merge with the company or other legal entity that is not cooperative or take the form of the company or other legal entity (Art. 5 par. 2 LOC).

However, the above mentioned assertion, about the legal nature of the cooperative, is not in accordance with the reformed cooperative rules, which are mainly encountered in the EU Regulation 1435/03 (Fici, 2013), aiming to bring closer the rules governing cooperatives with the respective ones applicable to companies. ${ }^{14}$ The Regulation contains provisions which deviate from the conventional principles and rules of the cooperative law. Firstly, unlike the LOC, according to which the member of a cooperative society can only be a person who either operates through the cooperative, uses its services or in any other way directly participates in achieving objectives for which the cooperative was established (Art. 3), Regulation (Art. 14 par. 2) contains deviation from the principle of identity, because the status of a cooperative member can also have an entity who invests capital (thus acquires certain property and management rights in the

12 For example, Art. 2. of Croatian LOC, Art. 6. Uniform Act on Cooperatives, enacted by OHADA, December 15, 2010.

13 These principles are different from those which are characteristic for the operation of other business entities

14 In France, the debate about the legal nature of cooperatives is ad acta since 1947 and adoption of the respective rules according to which cooperatives are considered as a form of commercial companies (Ripert, Roblot, 1998).

EP 2017 (64) 3 (1205-1218) 
cooperative) without any intention to use the goods or services of the cooperative (the so-called members non-beneficiaries or members investors). ${ }^{15}$ Second, the principle of open membership is basically limited. According to the applicable the rules of LOC, the status of members of the cooperative is acquired if the competent authority accepts the request for membership (if the request is not accepted, it may be appealed to the general meeting) (Art. 25). And, when it comes to members investors, they can acquire that status only if the general meeting accepts the request (not appealable) (Art. 14, par. 2 of the Regulation). It means that the cooperative is more closed than it is an open form of organization. Third, the rule that the cooperative is managed by its members, in accordance with the principle of "one member - one vote" (Art. 33 LOC), basically applies to the reformed rules. However, the Regulation contains exemptions from this principle, providing that: a) statute may determine that a member is entitled to a certain number of votes, determined according to his participation in the activities of the cooperative, and such attribution can not exceed five votes per member or $30 \%$ of the total voting rights; b) in the case of cooperatives engaged in financial affairs or insurance activities, the granted right to vote can not exceed five votes per member or $20 \%$ of total voting rights; v) non-user (investor) members can not have together more than $25 \%$ of the total voting rights; ${ }^{16} \mathrm{~g}$ ) the participation of employees' representatives in the general meetings or in the section or sectorial meetings, provided that the employees' representatives do not together control more than $15 \%$ of total voting rights (Art. 59).

In addition to the rules that fundamentally change the classic cooperative principles, ${ }^{17}$ in the Regulation, the guidelines encountered at numerous places suggest that cooperatives

15 In theory is expressed an attitude that even in the case of capital investment by persons who do not use the services of the cooperative, aim and purpose of the cooperative organization must be preserved, which is reflected in the maximum satisfaction of the needs of its members. This further means that the investor members may not have a decisive influence on the management in order not to come into a position to hinder the realization of benefits for beneficiary members (the so-called cooperative members) (Nilsson, 1999).

16 In France, investor members can not together own more than 35\% of votes. Similarly, in Italy, investor members can not have more than a third of the votes (Avsec, 2009).

17 In an effort to encourage reform of the cooperative sector, the European Commission in its Communication on the promotion of cooperatives - Brussels, 23.2.2004, COM(2004)18 - recommends to the Member States to base its legislation on cooperative values and principles, but at the same time to take into account the needs of the cooperatives for market competition with other business entities. In this regard, in theory it was attempted to come up with an answer to the question what is the essence of cooperatives, that is to say, of which principles it can be receded, and that it still can be talked about the cooperative (Avsec, 2009). 
are nothing but a kind of company ${ }^{18}$ to which apply the rules that also apply to joint stock companies. ${ }^{19}$ Thus, Preamble to the Regulation indicates that companies of all types should allow operations at the Community level (item 2). Or, that the regulations governing joint stock company apply to the cooperative in terms of: the appointment of experts and the valuation role (Art. 4, par. 6); publication of the registered data and documents (Art. 11 par. 5); issues relating to the status change of the merger - the draft of the contract, the publication of the draft of the contract, a report by independent experts, control of the legality of the merger, the announcement of completion of the merger (Art. 20, 22, 24, 26, 28, 29, 30, 32).

Based on these findings, it can be said that the reformed cooperative has a nature sui generis of the company to which the rules governing joint stock companies or limited liability companies apply on issues that are not regulated by the cooperative regulations. ${ }^{20}$

\section{The legal framework for the organization and business activities of cooperatives}

Cooperatives as a sui generis entity are characterized by certain specific rules which differentiate them from the companies. These rules form the special legal framework for their establishment and operation. Among those rules, out of particular importance for the existence of cooperatives as separate legal entities, are the rules that define: a) the number of the founders of the cooperative; b) membership in a cooperative; v) activity; g) the share capital; d) the right to vote, quorum and decision-making; f) profit distribution.

A) In contrast to companies that may be established by one or more founders, rules on cooperatives require higher number of founders, which is particularly noticeable in

18 In the OHADA Uniform Act there are not provisions about which rules apply to the regulation of matters not regulated by cooperative rules, whereas the art. 21 provides that, depending on the activities performed by the cooperatives have a civil or commercial character, from which it could be concluded that when they have a commercial character, if necessary, the provisions of the law regulating the status of companies shall apply.

19 In Art. 13. LOC it is determined that on issues that are not regulated by law, provisions of the law governing the legal status of limited liability companies apply (in Art. 34, par. 2 stipulates that on the responsibility of members of the authorities of the cooperative to the cooperative apply the provisions of the law that regulate the position of the companies, in the part regulating specific functions to the society, unless this law provides otherwise). The Croatian LOC (Art. 24, 29, 44) determines that the relevant provisions of the Companies Act apply to be the responsibility of the members, that is to say, on the process of merger, acquisition, division and liquidation apply provisions governing joint stock companies.

20 In Italy, depending on the number of members and the amount of assets, there is the possibility that the statute shall only determine which rules apply to the cooperative. If the cooperative has more than 20 members, and assets not exceeding one million euros, then the statute may provide that on the cooperative apply the provisions governing limited liability companies (if the above criteria are exceeded, then the rules governing joint stock companies apply) (Avsec, 2009).

EP 2017 (64) 3 (1205-1218) 
the former rules. ${ }^{21}$ In order to facilitate the establishment of cooperatives, especially farmers in the villages where there has been a substantial decline in the number of inhabitants, according to the applicable LOC, the minimum number of founders is reduced to five, except that this number can not consist of people who live in the same household with the founder (Art. 15). ${ }^{22}$

B) According to the LOC, cooperative is a special form of organization of natural persons (Art. 2) and consequently the status of its members can only have the natural (not legal) person (Art. 3). These guidelines differ from the regular, according to which cooperatives are not any particular form of organization of natural persons, which means that there are no obstacles to the founders of the cooperative to appear as natural and legal entities. ${ }^{23}$ In addition, the denial of legal entities to acquire the status of member cooperatives, the cooperatives are held in a subordinate position in relation to companies contrary to the above mentioned recommendations on the need to provide to the cooperatives additional opportunities to raise capital and provide the same conditions for business, that the other economic entities have (Timčić, 2016).

By the applicable cooperative rules, not only that the circle of its members is limited, according to the type of subjects, but also according to the principle of identity, the effects of which are kept in absolute terms, it is provided that the status of the cooperatives among natural persons can only have those who are service beneficiaries of the cooperative (the so-called cooperative members), but not those who would like to invest the capital in the cooperative, as set out in the EU Regulation 1435/03.

Potential cooperative members can become members of the cooperative if they fulfil additional requirements in terms of: entry of the lowest amount of capital (if the cooperative members invest a share in cooperative $)^{24}$; activities of the cooperative and their personalities; admission (making decision by the competent authority, which has been discussed above). In principle, the cooperative rules (statute) determine the minimum value of each share (it can be also determined by the law), ${ }^{25}$ which does not

21 According to the previously valid LOC, a housing cooperative could establish at least 30, and other cooperative types (except the students) at least ten natural persons (Art. 9).

22 According to the LOC of Croatian Republic for the establishment of the cooperative there should be at least seven founders (Art. 6, p. 1). The EU Regulation provides that the cooperative may set up five or more natural persons, provided that it can be established by two or more legal entities (art. 2). The OHADA Uniform Act has no explicit provisions on the number of founders, provided that the concept of cooperative (cooperative is an independent group ....- Art. 4) may conclude that there should be several founders.

23 In this respect: Art. 6 par. 2. LOC of Croatian Republic; Art. 2. of the Regulation; Art. 7. of the OHADA Act.

24 If the cooperatives are established without the shares of its members, funds for the establishment and operation are provided from the membership fees (Art. 22, par. 1).

25 LOC of Croatian Republic contains a provision according to which the share can not be less than 1,000 kunas, with the fact that the Parliament has the right to determine the share (Art. 31 par. 3$)$. 
have to be identical (Art. 20, par. 5 and 8 LOC). ${ }^{26}$ As far as the conditions relating to the activity and personality, in order to prevent fictitious cooperatives, it is determined in the LOC that the acquisition of the status of the cooperative members: in agricultural cooperative it is necessary that the entity is engaged in business activity determined by the cooperative; in the student-youth cooperative it is necessary that the entity is not younger than 15 years nor older than 30 years (Art. 23, par. 4 and 5).

C) In contrast to, for example, the OHADA Act which stipulates that the cooperatives can perform activities in all areas of human activity (Art. 5), the LOC stipulates that cooperatives can carry out lawful activities (Art. 9 par. 1), i.e., that can perform activities that are not prohibited by the law (Art. 11, par. 14). Since the deposit and credit transactions may be performed only by banks (Art. 5 of the Law on Banks), the cooperatives can not perform savings-loan transactions, which is the reason why in the LOC, unlike the previously applicable LOC (Art. 3, par. 3), the savings and loan cooperatives are not mentioned (Timčić, 2016).

D) The minimum share capital of the cooperative, founded with the shares of its members, is 100 dinars (Art. 20, par. 4 LOC). ${ }^{27}$ This solution is in line with the attitude that the rules governing limited liability companies apply to the cooperatives, which is the reason why the same minimum capital required for the cooperatives is also required for the establishment of these companies.

In order to preserve the sense of cooperative organization and the cooperative rule that service beneficiaries have control of management, in cases where it is allowed that the so-called non-beneficiaries have the status of cooperative member, two legal mechanisms are used, one of which is a limited right of investors to participate in the share capital (the other is limited right to vote). In this regard, the Spanish cooperative legislation primarily allowed investor members to participate in the share capital up to $33 \%$ of the share sums of cooperating members, and then share amounts up to $45 \%$ of all deposits (Avsec, 2009).

E) In accordance with the classic cooperative principle "one cooperative member - one

26 LOC contains a solution that is similar to that of the Regulation which determine that the nominal value of the share is determined by the statute, that the cooperative may issue different types of shares that give different rights in terms of share of the profit (shares that give the same rights make the same share type) (Art. 4. par. 1-3).

27 Concerning the minimum capital there are two solutions: in some jurisdictions it is left to the cooperatives in the statute to determine a minimum amount of share capital (Spain, US Uniform Law on Cooperative Associations), while in others the minimum amount of capital is determined by the relevant regulations. Thus, according to Regulation EU the minimum share capital amounts EUR 30,000 (Art. 3, par. 2), in Belgium, 18,550 euros, 50,000 Czech crowns (Avsec, 2009).

EP 2017 (64) 3 (1205-1218) 
vote", the LOC provides that cooperative members have equal voting rights (Art. 33$)^{28}$ and that the decisions are made by a majority votes of the present members, except in cases when it is stipulated that decisions are taken by qualified majority (Art. 35 and 36). However, the effect of this principle is not absolute anymore, deviations are possible (the aforementioned Art. 59 of the EU Regulation) that is to say, as a rule, they are required when the cooperative has investor members. In this regard, different solutions were adopted. Under the ULCAA, each investor member has one vote if it is not otherwise specified by rules. This means that they can have more votes, but also that they do not have to have the right to vote at all. In Wisconsin it is determined that the voting power of cooperating members must not be reduced to less than $51 \%$ of the votes of all members. In Italy, investor members can not individually have more than five votes, and all together they can have one third of the votes at the general meeting of the cooperative. In Spain, the investor members can have up to $30 \%$ of the total number of votes (Avsec, p. 99, 105, 106, 116).

In addition to limitations on the number of votes of investor members, in order to ensure management control by the cooperating members, specific conditions are determined regarding quorum and decision-making. In order to prevent out-voting of the beneficiary members by investor members, the EU Regulation 1435/03 indicates that the statute should determine the specific requirements for a quorum regarding beneficiary members (Art. 61). Or, the ULCAA does not define a quorum (unless it is otherwise determined by the cooperative rules, quorum requirement is met, regardless of the number of the present members), but gives particular weight to the cooperating members providing that: 1) the total number of votes shall not be less than the majority of the total number of votes (cooperating members and investor members); 2) and that the decision is considered adopted if it has the majority of votes of all members and the majority of beneficiaries (the system of double majority) (Avsec, 2009).

F) In accordance with the principle of economic participation of members (Art. 4, par. 3 , item. 3 LOC) in the business and development of the cooperative, the cooperative members participate ${ }^{29}$ in the distribution of profits in proportion to their share in the cooperative and the value of the turnover carried out through the cooperative, having covered losses from the previous period and the input of resources in the funds for different purposes (reserve fund, cooperative fund, used for investment or the capital

28 Similar provision is also contained in the other legal sources: in OHADA Act states that every member has one vote regardless of the amount of their participation in the cooperative share capital (Art. 102). Or the EU Regulation stipulates that each member has right to one vote regardless of the number of shares it holds (Art. 59, par. 1).

29 Statute (cooperative rules) may prohibit any surplus distribution (Art. 67, par. 3 of the EU Regulation). In this sense, the Croatian LOC stipulates that in the cases when cooperative activity is performed solely for the purpose of meeting the needs of their members (social, consumer, housing cooperative), when it has not been established with the aim of gaining surplus or when it is funded from the membership fees (non-profit organization), surplus is transferred to the next year after covering deficits (Art. 38). 
increase), if they are educated (art. 59 LOC). ${ }^{30}$

According to the EU Regulation 1435/03, the legal reserve fund (in Serbian law this fund is optional) is equal to the share capital and the amount entered to it may not be less than $15 \%$ of the surplus for the financial year after deduction of any losses carried over (Art. 65). Given that under the EU Regulation members of the cooperative may also be investor members, it is stipulated that the balance of the surplus after deduction of the allocation to the legal reserve, of any sums paid out in dividends ${ }^{31}$ and of any losses carried over, with the addition of any surpluses carried over and of any sums drawn from the reserves, shall constitute the profits available for distribution (Art. 67, par. 1). The Regulation does not explicitly specify whether the entire surplus can be shared (including the one that arises from conducting business with non-members) or just the one arising from business operations of the cooperative with its members, nor is determined the ratio in which they can participate in the distribution of surplus of beneficiary and investor members. On that occasion, the ULCAA stipulates that the share of beneficiary members in profits can not be reduced to less than $50 \%{ }^{32}$

\section{Conclusion}

For organizations such as cooperatives, that set up the beneficiaries of their services at the center of their activities, and which can overcome crisis periods in a more efficient manner in comparison to companies, it should be expected that cooperatives become the preferred organizational form of association of interested parties in the future. Consequently, legal acts of many countries emphasize the need to improve cooperative business and bring it in line with the operation of other legal entities. In this regard, the ongoing reforms of the cooperative sector, primarily under the influence of the EU Regulation 1435/03 and the ULCAA, are basically directed towards the corporatisation of the cooperatives, by reducing the difference between the cooperatives and the companies, with notable resistances in respect of such reforms in some jurisdictions.

Serbian cooperative legislation, apart from minor changes (amount of share capital, unequal shares, the application of the rules governing limited liability companies),

30 Unlike our LOC, cooperative rules of the Republic of Croatia specify that after deduction of any losses, at least $20 \%$ of surplus is directed for the development of cooperatives and at least $5 \%$ for the legal reserves, until the reserves reach the total amount of the member's shares (Art. 37 par. 2).

31 In Italy, investor members may, in accordance with the statute of the cooperative, receive part of the profits at the rate of two per cent higher than the rate for dividends that cooperative may pay to the user members. In the US state of Delaware to user members may receive dividends at the rate of up to six percent, and to the investor members at a rate of up to $12 \%$ (Asvec, 2009).

32 In the US state of Wisconsin profits distributed to beneficiaries may not be less than 51\%, provided that this percentage can be reduced up to $30 \%$ on the basis of the founding act or statute, with the approval of cooperating members. In the US state of Wyoming proportion of beneficiaries in total profit must not be lower than 15\% (Asvec, 2009).

EP 2017 (64) 3 (1205-1218) 
essentially remains on the positions of the previously applicable, classic cooperative concept. For the purpose of approaching and harmonization with the modern trends of the cooperative organization, but also in favour of the preservation of the cooperative as a specific form of organization, it is necessary: to alter the attitude of the cooperative as a form of organization of natural persons; relativize the effect of the principle of one cooperative member - one vote, self-help and identity in order to strengthen the market functions of the cooperative; to protect the purpose of the cooperative organization to the maximum, and that is the satisfaction of the interests of the cooperative beneficiary members. In the case of changing the structure of its members, the conflict of interest between cooperating members and investor members must be taken into account (the first are primarily interested for more favorable business conditions, and the other in greater benefits), in order to achieve the maximum interest of both groups for the successful operation of cooperatives.

\section{Literature}

1. American Uniform Limited Cooperative Association Act (ULCAA), (available at: $\quad$ http://www.uniformlaws.org/shared/docs/limited $\% 20$ cooperative $\% 20$ association/ulcaa final 07.pdf).

2. Avsec, F. (2009): Članstvo korisnika i investitora u zadruzi: uporedni pregled uređenja u evropskom privrednom prostoru i SAD, Strani pravni život, vol. 53, no. 2, pp. 85-126, Institut za uporedno pravo, Beograd, Srbija.

3. Borzaga, C., Galera, G. (2012): Promovisanje zadruga u stvaranju boljeg sveta, (available at: http://www.euricse.eu/wp-content/uploads/2015/03/venice croatian 3.0 0.pdf).

4. Communication from the Commission to the Council and the European Parliament, the European Economic and Social Committee and the Committee of Regions on the promotion of co-operative societies in Europe [COM(2004)18], Brussels, 23/02/2004 (available at: http://eur-lex.europa.eu/legal-content/EN/ TXT/?uri=CELEX:52004DC0018).

5. Fici, A. (2013): Pan-European Cooperative Law: Where Do We Stand?, European Research Institute on Cooperative and Social Enterprises, Working Paper, no. 47, pp. 1-12, Trento, Italy, (available at: http://www.euricse.eu/wp-content/ uploads/2015/03/1358347724_n2285.pdf).

6. Jurić, D. (2006): Europska zadruga, Pravo i porezi, vol. 15, no. 6, pp. 58-67, RRIF, Zagreb, Hrvatska.

7. Hagen, H. (2002): Aktuelne tendencije u uporednom zadružnom pravu, Pravo, teorija i praksa, vol. 19, no. 9, pp. 48-61, Univerzitet Privredna akademija, Pravni fakultet za privredu i pravosuđe, Novi Sad, Srbija.

8. Ibáñez, I.E. (2011): Law Applicable to the European Cooperative Society: special reference to the european cooperative established in Spain, European Company and Financial Law Review, vol. 8, no. 1, pp. 30-46, De Gruyter, Berlin, Germany. 
9. Izveštaj o zadrugama i zadrugarstvu, (available at: http://www.uciteljneznalica. org/upload/ebook/928_Izve\%C5\%A1 taj\%20o\%20zadrugarstvu.pdf).

10. Morel, S. (2014): Valorisation de l'histoire et du patrimoine des coop'eratives agricoles : L'exemple de la Loire, Saint-Etienne, (available at: https://tel. archives-ouvertes.fr/tel-00993464/document).

11. Nilsson, J. (1999): Cooperative Organisational Models as Reflections of the Business Environments, The Finnish Journal of Business Economics, vol. 48, no. 4, pp. 449-470, Association for Business Administration, Finland, (available at: http://ta.hse.fi/1999/4/1ta_1999 04 a6.pdf).

12. OHADA Uniform Act, (available at: http://www.ohadalegis.com/AUDSC2014. htm).

13. Popović, V. (2012): Zadrugarstvo i njegov značaj za razvoj privrede Republike Srpske, Pravo i privreda, no. 4-6, pp. 97-106.

14. Predlog Zakona o zadrugama, (available at: http://paragraf.rs/dnevnevesti/211215/211215-vest31.html).

15. Regulation EU 1435/03 of July 22, 2003 on the Statute of the European Cooperative Society, Official Journal EU, no. 207/03.

16. Ripert, G., Roblot, R. (1998): Traité de droit commercial, t. 1, L.G.D.J, Paris, France.

17. Timčić, A. (2016): Normativna određenja i ograničenja uslužnih delatnosti zadruga u Republici Srbiji, Zbornik: Usluge i uslužna pravila, Kragujevac, Pravni fakultet Univerziteta u Kragujevcu, Srbija, pp. 161-168.

18. Vitez, M. (1998): Zadruga i naše privredno pravo, Pravo, teorija i praksa, vol. 15, no. 5-6, pp. 21-31, Univerzitet Privredna akademija, Pravni fakultet za privredu i pravosuđe, Novi Sad, Srbija.

19. Zakon o zadrugama, Sl. glasnik RS, no. 112/15.

20. Zakon o bankama, Sl. glasnik RS, no. 107/2005, 91/2010 and 14/2015.

21. Zakon o zadrugama Republike Hrvatske, Narodne novine, no. 34/11, 125/13, 76/14.

22. Zakon o trgovačkim društvima Republike Hrvatske, Narodne novine, no. 111/93, 34/99, 121/99, 52/00, 118/03, 107/07, 146/08, 137/09, 125/11, 152/11, 111/12, $68 / 13,110 / 15$. 


\section{PRAVNA PRIRODA I OKVIR ZA POSLOVANJE ZADRUGA}

\section{Miodrag Mićovic ${ }^{33}$}

\section{Rezime}

U radu je najpre ukazano na značaj koji zadruge imaju za stabilnost privrednog ambijenta, a zatim je izvršena uporednopravna analiza pitanja vezanih za pravni položaj zadruga $i$ onih kojima se definiše pravni okvir za organizaciono i poslovno delovanje zadruga. Kada se radi o pravnom položaju zadruga, novodonetim pravilima nisu izvršene suštinske promene u odnosu na ranije važeći klasični koncept zadruge kao sui generis udruženja. Što se tiče pravnog okvira zadružnog delovanja, njega karakterišu određene posebnosti (pravila) po kojima se zadruge razlikuju od privrednih društava, a to su: broj osnivača zadruge; lica koja mogu da budu zadrugari; delatnost; osnovni kapital; pravo glasa, kvorum i donošenje odluka; raspodela dobiti.

Ključne reči: zadruga, zadrugar, pravo glasa, principi, članovi investitori

33 Redovni profesor, dr Miodrag Mićović, Univerzitet u Kragujevcu, Pravni fakultet, Ulica Jovana Cvijića br. 1, 34000 Kragujevac, Srbija, Telefon: +381 34306 530, E-mail: mmicovic@jura.kg.ac.rs. 